\title{
Corporate Social Responsibility (CSR) and Earnings Management (EM): An Analysis from the National Culture Perspective
}

\begin{abstract}
:
This research investigates the influence of national culture dimensions on the relationship between corporate social responsibility (CSR) and earnings management (EM) in order to understand whether the culture of countries influences the informational behavior of companies engaging in CSR activities. We evidenced that the social and environmental practices have a negative relation with the ones of the EM in the 19,635 companies located in the 24 countries, in an analysis without considering the influence of the national culture. By inserting Hofstede's cultural dimensions, we find that individualism, masculinity, and indulgence impact CSR and EM practices, so that companies seem to get more involved with EM and also to disclose more social and environmental practices, is in line with the opportunistic approach of CSR. On the other hand, we show that the power distance influences for a negative relationship between CSR and EM, which reveals that organizations maintain their informational behavior in this context. These results were confirmed for the total sample of 157,080 observations and also for the sample generated through the Propensity Score Matching, which matched 37,428 observations from companies that disclose CSR practices or not, considering the matching between sizes and industries. These findings may contribute to the literature by explaining the range of divergent results on CSR and EM, generating evidence that some dimensions of national culture may help to explain why, in certain scenarios, CSR has a positive relation to EM, while in others, it shows the opposite. Moreover, through this evidence, organizations, especially those with subsidiaries/affiliates in other countries, can focus on control mechanisms aimed to mitigate the opportunistic behavior of managers, triggered by the cultural influence of individualism, masculinity, and indulgence.
\end{abstract}

Keywords: Corporate Social Responsibility; Earnings Management; National Culture.

\section{INTRODUCTION}

Several researchers have investigated the relationship between corporate social responsibility (CSR) and earnings management (EM) practices, such as Martínez-Ferrero and García-Sánchez (2015), Muttakin, Khan, and Azim (2015), Bozzolan, Fabrizi, Mallin and, Michelon (2015), Martinez-Ferrero, Gallego-Alvarez, and García-Sánchez (2015), Ko and Kim (2015), Gras-Gil, Manzano, and Fernández (2016), Gavana, Gottardo, and Moisello (2017), Hsu and Chen (2017), Patro and Pattanayak (2017), Jordaan, Klerk, and Villiers (2018) and 
Kim, Udawatte, and Yin (2018). However, the results have been divergent, with some revealing a positive relationship between CSR and EM, while others a negative one.

The negative relationship between CSR and EM assumes that by engaging in voluntary disclosures on social and environmental issues, companies are transparent to their stakeholders, i.e., they disclose more information and are more informational. While they value information transparency, they are also concerned with the quality of this information, as they are less involved in EM. This view is called by Kim, Park, and Wier (2012) as an ethical approach to CSR because, according to the authors, the commitment of organizations with their stakeholders motivates this behavior. In this research, we adopted the term "informational" to represent companies that have greater transparency (higher CSR) and information quality (lower EM).

The positive relationship between CSR and EM, in turn, presupposes that CSR is a simple means of wealth creation and that any social or environmental practice undertaken is accepted if and only if it is consistent to make a profit. For Kim et al. (2012), managers engage in CSR practices intending to obtain personal benefits, rather than for the interests of the company and stakeholders. Therefore, from this point of view, CSR may be linked to the pursuit of managers' particular interest and, therefore, to the larger EM (Kim et al., 2012). We call this view as "opportunistic."

In this research, we chose to position ourselves theoretically on the informational view of CSR, because we believe that companies that perform CSR practices tend to manage the earnings less intensely, as they have transparency and reliability incentives. We justify our position by the Chih, Shen, and Kang (2008), who investigated a comprehensive sample of 46 countries and by Martinez-Ferrero et al. (2015), who analyzed the two-way relationship between CSR and EM and found that both showed a negative relationship. 
We observed in previous studies the attention given to the search for evidence on the conduct of organizations that engage in CSR in different contexts (whether informational or opportunistic), but we realized that research has not focused on investigating why there are different outcomes. Therefore, the gap identified in this study refers to the possibility of investigating factors that impact on the relationship between CSR and EM, in order to highlight possible explanations as to why in some contexts there are positive and in others negative results.

In order to theoretically support this concern, we observed three studies that presented suggestions for progress in investigating CSR and EM. The first one is Martínez-Ferrero and García-Sánchez (2015), who highlighted that country-level factors could help explain the relationship between CSR and EM. The research by García-Sánchez and García-Meca (2017) suggested the use of the cultural dimensions of Hofstede, Hofstede, and Minkov (2010) as country-level factors that could influence the relationship between CSR and EM, and Kim et al. (2018) research, which recommended the insertion of national culture as an explanatory factor for the relationship between EM and CSR.

We believe that national culture can influence the relationship between CSR and EM in order to attenuate or enhance the negative relationship (informational approach) between CSR and EM. In some cases, we understand that in addition to mitigating the negative relationship between these subjects, cultural dimensions can trigger a positive relationship, which would help to explain previous study results and support the opportunistic approach to CSR practices.

Gray (1988) supports the premise that national culture can influence this relationship; he developed the approach to cultural influence, which considers culture to be a key factor in understanding the social sciences. Accounting, being characterized as social science, is influenced by cultural aspects, which are responsible for shaping different norms, values, and behaviors for each nation. 
Gray's (1988) approach to cultural influence uses the national culture model proposed by Hofstede (1980), who published its latest version in 2010 (Hofstede et al., 2010), which points to six cultural dimensions: power distance, individualism versus collectivism, masculinity versus femininity, uncertainty avoidance, long-term orientation versus short-term orientation and indulgence versus restraint. We assume that each of these dimensions influences the relationship between CSR and EM. Therefore, we aim to analyze the influence of national culture dimensions on the relationship between CSR and EM practices.

The main contribution of this study is to fill a research gap on a factor that possibly impacts the relationship between CSR and EM: national culture, not considered in previous research (Muttakin et al., 2015; Martinez-Ferrero et al., 2015; Gavana et al., 2017; Hsu \& Che, 2017; Gras-Gil et al., 2016; Jordaan et al., 2018; Kim et al., 2018). Thus, we seek to generate evidence that cultural characteristics are country-level factors to be considered when investigating the relationship between CSR and EM, which was theoretically suggested by Martínez-Ferrero and García-Sánchez (2015), García-Sánchez and García-Mecca (2017) and Kim et al. (2018). Such cultural characteristics can help to explain the conduct of organizations that engage in CSR and EM practices, as well as to understand the context of empirical divergences evidenced by previous research.

Practically, we seek to contribute to organizations, especially those with subsidiaries/affiliates in other countries, which through empirical evidence of the impact of national culture, can insert control mechanisms focused on CSR and EM practices to ensure that such practices are responsible for generating greater transparency and quality of information. On the other hand, companies can avoid excessive expenses in the insertion of control mechanisms of CSR and EM practices when their organizations face cultural characteristics that already induce them to use these practices in an informational way. 
We also seek to contribute to shareholders and investors, who, through this evidence, can pay attention to the cultural characteristics of the countries in which organizations operate, when deciding on their investments. Shareholders may require control mechanisms to ensure that CSR and EM practices reflect informational conduct and reliably inform business reality to stakeholders.

\section{BACKGROUND AND HYPOTHESES DEVELOPMENT}

\section{Background and Prior Literature}

Socially responsible behavior from part of companies, according to Ali, Frynas, and Mahmood (2017), has gained notoriety in the academic community since the 1980s. However, previous studies such as Davis (1973) have shown that companies, although being economic institutions, had a significant influence on society and, therefore, should use their economic resources in an altruistic manner.

Research such as Brooks and Oikonomou (2017) sought to discuss why companies invest and disclose CSR if these practices are not mandatory. The authors discuss two main views, which are highlighted by them as motivations for CSR practices. One of these views is what we call an informational approach, while the other is opportunistic.

Previous studies that investigated CSR have related it to the EM measure, seeking to show if the organizations present a behavior of greater transparency and quality of information (negative relation between CSR and EM) or an opportunistic behavior, in which they disclose actions of CSR in order to mask accounting manipulation practices (positive relationship between CSR and EM).

We reviewed previous studies from 2008 and found 11 that found a positive relationship between CSR and EM by the discretionary accruals metric (Prior, Surroca, \& Tribó, 2008; Gargouri, Francoeur, \& Shabou, 2010; Salewski \& Zulch, 2014; Martínez- Ferrero \& García- 
Sánchez, 2015; Muttakin et al., 2015; Carey, Li, Liu, \& Qu, 2017; Gavana et al., 2017; Patro \& Pattanayak, 2017; Jordaan et al., 2018; Kim et al., 2018) and nine studies that found a negative relationship (Chih et al., 2008; Kim et al., 2012; Martínez-Ferrero, García-Sánchez, \& Cuandrado-Ballesteros, 2013; Bozzolan et al., 2015; Cho \& Chun, 2015; Martinez-Ferrero et al., 2015; Ko \& Kim, 2015; Gras-Gil et al., 2016; Hsu \& Chen, 2017).

We found that those that show a negative relationship between CSR and EM mostly cover a larger number of countries, such as Chih, Chen, and Kang (2008), that considered companies from 46 countries. Martinez-Ferrero et al. (2015), in addition to analyzing 26 countries, also investigated the two-way relationship between CSR and EM, and in both cases, found a negative relationship. This context of previous studies leads us to argue about the negative relationship between CSR and EM, which we believe can be acted upon or enhanced by the dimensions of national culture.

The premise that national culture can assist in explaining the relationship between CSR and EM derives theoretically from the approach of cultural influence (Gray, 1988). Gray's study (1988) has broadened earlier research, which until then had only considered differences in the economic, legal, and political system as relevant factors for better understanding companies as accounting systems. The author focused his discussion on the influence of national culture, based on Hofstede's (1980) research.

Hofstede (1980), Hofstede (1991) and Hofstede et al. (2010) gave rise to a national culture model based on six cultural dimensions: power distance, individualism versus collectivism, femininity versus masculinity, uncertainty avoidance, long term orientation versus short term orientation, and indulgence versus restraint. 


\section{Hypothesis 1}

The power distance, according to Paredes and Wheatley (2017), is related to the hierarchy and the level of authority given to the main managers. In countries with high levels of power distance, the hierarchy and authoritarianism of managers will be greater. As such, they can exercise greater power to manage operations, as the higher hierarchy makes them less likely to be questioned by their subordinates about their attitudes.

For Gray, Kang, Lin, and Tang (2015), the high-power distance tends to positively influence the EM, considering that in this cultural configuration, managers are more likely to abuse their power to manage earnings and thus achieve personal goals. Similarly, Ugrin, Mason, and Emley (2017) argue for a positive relationship between EM and high-power distance, as subordinates are more likely to tolerate dubious practices from their superiors when they are culturally compliant with them.

Taylor and Curtis (2013) believe that when subordinates perceive that their superiors are performing inappropriate attitudes, they are less likely to report such attitudes when they are in a context of high-power distance. Such a process makes managers feel more comfortable in performing such actions.

Empirically, the research by Nabar and Boonlert-U-Thai (2007), Doupnik (2008), and Ugrin et al. (2017) did not find statistical significance in their results, while Gray et al. (2015) found a positive relationship between the high-power distance and the EM.

Based on the above, we understand that the negative relationship between CSR and EM, based on the informational view, maybe attenuated in countries with high power distances, as this cultural dimension tends to enhance the opportunistic behavior of managers. In this case, it is also possible that the relationship between CSR and EM becomes positive, which would help 
to explain the implementation of CSR practices in an opportunistic manner. Based on this, we elaborate hypothesis $\mathrm{H} 1$ :

H1: The cultural dimension of high power distance attenuates the negative relationship between CSR and EM practices.

\section{Hypothesis 2}

Regarding individualism, there is a divergence between the theoretical positions of the research that supported the relationship with the EM. For example, Desender, Castro, and León (2011) argue that in individualistic societies, EM is lower because, in this scenario, the group is more likely to disclose the misconduct of its managers and, therefore, it is difficult to cover up such practices. Similarly, Ugrin et al. (2017) suggest that collectivist societies are prone to coexist and conform to opportunistic practices, which allows us to assume that individualistic societies would be less prone to EM.

On the other hand, Han, Kang, Salter, and Yoo (2010) support the idea that individualism instigates the EM, considering that the high level of individualism makes managers flexible in their reports and giving space to the disclosure of more optimistic numbers.

In addition to different understandings about the relationship between EM and individualism, the empirical results also reveal divergent relationships. Nabar and Boonlert-UThai (2007) and Doupnik (2008) found a negative relationship between individualism and EM, which supports the idea that in individualistic societies, companies manage earnings less intensely. On the other hand, Han et al. (2010), Gray et al. (2015), and Ugrin et al. (2017) observed a positive relationship between EM and individualism, suggesting that companies in individualistic societies manage earnings with greater intensity.

In considering these latter studies, we argue that the negative relationship between CSR and EM (informational approach) may be attenuated in individualistic countries, as this cultural 
dimension tends to enhance the opportunistic behavior of the manager. In this case, it is also possible that the relationship between CSR and EM becomes positive because individualism possibly induces an opportunistic behavior of managers, which would help explain the practice of CSR practices in an opportunistic manner. Thus, we formulate the hypothesis $\mathrm{H} 2$ :

H2: The cultural dimension of individualism attenuates the negative relationship between CSR and EM practices.

\section{Hypothesis 3}

Masculinity, according to Paredes and Wheatley (2017), can be perceived as a cultural characteristic aimed at valuing material, career, money, and economic growth issues. Therefore, for the authors, managers of companies from countries with male characteristics tend not to worry about external interests and to prioritize their interests and, thus, manage the earnings with greater intensity. Similarly, Gray et al. (2015) compare male and female societies, arguing that the former tends to prioritize personal and individual achievement as well as achievement in financial terms. Therefore, in male countries, managers would tend to use EM as a way to achieve their own goals.

Ugrin et al. (2017) support the positive relationship between a culturally male society and EM, believing that female societies are prone to reject opportunistic practices and therefore tend to inhibit EM. Doupnik (2008) and Nabar and Boonlert-U-Thai (2007) also support the positive relationship between masculinity and EM.

We observed a consensus on the authors' position on the expected relationship between EM and masculinity; however, regarding the empirical results, we observed the incipience of the findings. Gray et al. (2015) found a positive relationship, while Doupnik (2008), Nabar and Boonlert-U-Thai (2007), and Ugrin et al. (2017) did not reach statistically significant results.

We hope that masculinity has a positive relationship with the EM, based on the theoretical precepts that in these societies, managers prioritize their private interests, which instigates them 
to the greater EM. Therefore, we expect an attenuation of the negative relationship between CSR and EM, and managers' informational conduct regarding their CSR practices will be reduced and may even become opportunistic behavior. In this sense, we elaborate hypothesis H3:

H3: The cultural dimension of masculinity attenuates the negative relationship between CSR and EM practices.

\section{Hypothesis 4}

Gray (1988) supported the premise that uncertainty avoidance was associated with rigid rules and greater control, with the primary intention of trying to prevent uncertainty situations. Han et al. (2010) empirically proved this assumption related to the EM, showing that companies from uncertainty-prone countries tend to manage the earnings with less intensity since they have stricter rules and controls.

On the other hand, Doupnik (2008) and Ugrin et al. (2017) understand uncertainty avoidance from a performance perspective, which takes the assumption that managers in uncertainty avoidance countries avoid negative financial performance as much as they believe this has negative consequences for the company. Therefore, they try to make profits, which can instigate a higher EM. In countries with low uncertainty avoidance, in turn, managers are not so concerned about disclosing negative performance, as they are less concerned about the uncertain consequences of such disclosure. In this scenario, managers are likely to manage earnings less because they do not realize the need to manipulate the profits (Ugrin et al., 2017).

The empirical findings present results that support both understandings about uncertainty avoidance and EM. For example, Nabar and Boonlert-U-Thai (2007), Doupnik (2008), and Ugrin et al. (2017) found a positive relationship between EM and uncertainty avoidance, which supports the view that managers more intensely manage earnings in such environments, as they are reluctant to present negative earnings. On the other hand, Han et al. (2010) and Gray et al. 
(2015) found a negative relationship between EM and uncertainty avoidance, which supports the view that in this scenario, there are more rules and regulations, which minimizes EM practices.

Based on the premise of the negative relationship between EM and uncertainty avoidance, we assume that the negative relationship between CSR and EM is enhanced in companies culturally exposed to high uncertainty avoidance. As a result, if companies manage earnings less, they tend to disclose their CSR information in an informational manner. Given the above, we formulate hypothesis $\mathrm{H} 4$ :

H4: The cultural dimension of uncertainty avoidance enhances the negative relationship between CSR and EM practices.

\section{Hypothesis 5}

Hofstede's fifth cultural dimension refers to a short- or long-term orientation. According to Gray et al. (2015), to understand the relationship between this cultural dimension and the EM, we must understand that the practice of EM aims to achieve short-term goals or manipulate a certain value in a short period. Thus, it is simple to understand that long-term orientation tends to be negatively related to EM.

The same understanding, we see in Dupnik (2008) and, more recently, in Ugrin et al. (2017). According to the latter, short-term oriented societies are more likely to manipulate profits to stabilize or increase them in the current period, without worrying about future negative effects. Therefore, we assume that long-term orientation makes managers worry about the future of the organization, which consequently encourages the lowest EM.

Regarding the empirical results, Gray et al. (2015) identified the opposite relationship to the expected. To justify this finding, the authors pointed out that their assumption is that profit targets are short-term when they can be long-term. Also, for Gray et al. (2015), there may be an informative EM, which aims to disclose private information about the organization in order 
to make the information of higher quality, and not less, as the opportunistic aspect of the EM suppose. For the authors, one can accomplish this type of EM by focusing on long-term goals, which would justify the higher EM in long-term oriented societies.

Although there are different explanations for the relationship between EM and a longterm orientation, this study relies on the theory supported by Dupnik (2008) and Ugrin et al. (2017), that long-term cultures tend to manage earnings less intensely. This position is because the EM, in itself, is perceived in this research as an opportunistic practice and, therefore, this understanding differs from that presented by Gray et al. (2015) in their justification for the positive relationship.

Given the above, we assume that companies located in countries with a long-term orientation culture show a higher negative relationship between CSR and EM. This assumption stems from the fact that if this cultural dimension induces organizations to manage earnings less intensively, then this will further enhance organizations' informational behavior concerning their CSR practices. Given the above, we established hypothesis H5:

H5: The cultural dimension of longer-term orientation enhances the negative relationship between CSR and EM practices.

\section{Hypothesis 6}

Finally, the last cultural feature of the Hofstede model - indulgence versus restraint - was investigated only by Ugrin et al. (2017). The authors understand that the lack of studies that investigated this cultural dimension is justified for the fact that only in 2010 Hofstede included it in his model.

According to Ugrin et al. (2017), countries with restrictive characteristics have laws, rules, and restraints that primarily aim at the order of society. Therefore, the authors suggest that more indulgent countries, which are, in terms of customs, more liberal and less restrictive, 
have more incentives for EM. The results evidenced by the authors confirmed the positive relationship proposed theoretically.

Based on Ugrin et al. (2017), we expect in this research a positive relationship between the EM and the cultural dimension of indulgence. Moreover, the negative relationship between CSR and EM may be attenuated in indulgent countries, because this cultural dimension encourages opportunistic behavior by the manager, which may even result in a positive relationship between CSR and EM. Thus, we elaborate on the H6:

H6: The cultural dimension of indulgence attenuates the negative relationship between CSR and EM practices.

\section{DATA AND METHODOLOGY}

\section{Data}

The research population comprised the companies located in the Group 20 (G20) countries that were part of the Hofstede (2010) national culture model and were available in the Thomson Reuters Eikon database in July 2017, when the data collection occurred. The choice of companies located in G20 countries was primarily due to their economic representativeness, as this group represents the 19 largest economies and the European Union. Also, the G20 provides a range of approximately 40 countries, which is relevant when analyzing cultural differences between countries. The sample comprised all companies that had the necessary information to calculate the research variables, as shown in Table 1, Panel A.

\section{[Insert Table 1 here]}

The population represented 37,397 companies located in 36 countries. From the population, we excluded companies that did not have information to calculate the dependent and control variables. Companies that did not contain information about the independent variable (CSR) were maintained to compose the control group. We exclude companies belonging to the financial sector (GICS Code 40) because, according to Lee, Byun, and Park 
(2018), they have different regulations, and we should not compare their financial statements with those of other sectors. Finally, we excluded companies from countries considered to be unrepresentative and countries where no company reported CSR.

The sample comprised 19,635 companies located in 24 countries, presented in Panel B of Table 1. In Panel C, we present the division of companies by the 11 sectors classified by the Global Industry Classification Standard (GICS). The sample was analyzed from 2010 to 2017 and is considered balanced, which totaled 157,080 observations.

The limitation of the analysis period was due to the greater amount of information on CSR released since 2010. For example, no Brazilian company disclosed CSR practices in 2009, and the following year, 36 companies started the CSR dissemination of such practices, which gradually increased in later years. Therefore, we understand that the year 2010 presented growth in the disclosure of CSR, both to Brazilian companies and other countries; therefore, we consider it as the base year for the study.

\section{[Insert Table 2 here]}

Table 2 presents the research sample divided between companies with and without CSR practices, during the eight years of analysis. We note that most companies did not disclose any CSR practices among those analyzed by the database, which at the end of the period made companies with CSR represent only $11.91 \%$ of the total 157,080 observations. Based on the percentage of companies that disclose CSR, we realize that these practices have been growing continuously over the years, and in 2010 only $8.68 \%$ of companies reported CSR, rising to $16.69 \%$ in 2017.

\section{Earnings Management Measure}

We measured EM by the discretionary accrual estimation model of Kothari, Leone, and Wasley (2005). Before the application of this model, total accruals were estimated based on the 
Balance Sheet, Income Statement, and Cash Flow accounts. To calculate the total accruals, we follow the one proposed by Dechow and Dichev (2002), and also used by Kothari et al. (2005).

We performed the econometric model proposed by Kothari et al. (2005) by the crosssection multiple linear regression (OLS) model by sector, year, and country, as showed in Equation 1.

$$
T A_{i t}=\delta_{0}+\delta_{1} \frac{1}{A_{i t-1}}+\delta_{2}\left(\Delta \text { Sales }_{i t}-\Delta R E C_{i t}\right)+\delta_{3} P P E_{i t}+\delta_{4} R O A_{i t}+\varepsilon
$$

$\mathrm{TA}_{\mathrm{it}}=$ total accruals, obtained by change in working capital, scaled by total assets in $\mathrm{t}-1$; $\mathrm{A}_{\mathrm{it}-1}=$ total assets of firm $\mathrm{i}$ in period $\mathrm{t}-1 ; \Delta \mathrm{Sales}_{\mathrm{it}}=$ change in sales, scaled by total assets in $\mathrm{t}-1$; $\mathrm{REC}_{\mathrm{it}}=$ change in accounts receivable, scaled by total assets in $\mathrm{t}-1 ; \mathrm{PPE}_{\mathrm{it}}=$ property, plant, and equipment gross, scaled by total assets in $\mathrm{t}-1 ; \mathrm{ROA}_{\mathrm{it}}=$ return on assets, scaled by total assets in $\mathrm{t}-1 ; \varepsilon_{\mathrm{it}}=$ regression error (proxy for EM by discretionary accruals); and $\delta_{0} ; \delta_{1} ; \delta_{2} ; \delta_{3} ; \delta_{4}=$ estimated regression coefficients.

The value of the error generated by the operationalization of the model by Kothari et al. (2005) represents the measure of EM. It is noteworthy that as the objective of this research is not to understand the EM performed to increase or decrease the earnings, we considered the residual values in absolute terms.

\section{Corporate Social Responsibility Measure}

We got the CSR information from the companies' ESG (Environmental, Social and Governance) report, available from Thomson Reuters Eikon. Previous research such as that by Liu et al. (2017) and Chollet and Sandwidi (2018) used these measures as a proxy for CSR. Liu et al. (2017) highlight that the availability of this information is still scarce, which stems from the fact that it is information disclosed voluntarily. 
To measure CSR, we consider the environmental and social dimensions present in the ESG report. Each dimension has categories, and each category has weights assigned by Thomson Reuters Eikon. The sum of the weights generates a proportionality value for each score. The social dimension is formed by the categories of the workforce, human rights, community and product responsibility, while the environmental dimension includes resource use, emission reduction and environmental innovation.

The workforce category measures the effectiveness of companies associated with job satisfaction in providing employees with a healthy and safe environment aimed at equal opportunity and workforce development. The human rights category measures the effectiveness of companies in respecting basic human rights conventions. The community category, in turn, has 14 items and measures companies' commitment to being a "good citizen" by protecting public health and respecting business ethics. Finally, the product responsibility score reflects the ability of companies to produce quality products and services, seeking to integrate their customers' health and safety and data integrity and privacy (Thomson Reuters Eikon, 2018).

\section{National Culture Measure}

To measure national culture, we used the model of Hofstede et al. (2010), because according to Esteban, Villardón, and Sánchez (2017), it is the most appropriate model to capture the similarities and differences between countries' cultures. Hofstede (2018) has a website that keeps the cultural dimensions up to date, so we use the scores available in the year 2018. Each of the cultural dimensions is measured by a scale from 0 to 100 , the closer to 100 the country is more a long-distance from power, individualistic, masculine, high uncertainty avoidance, long-term and indulgent (Hofstede, 2018), and the closer to 0, the opposite.

The power distance dimension measures whether the less powerful members of an institution expect and accept the unequal distribution of the hierarchy/power. Individualism 
measures the degree of interdependence that society maintains among its members. Masculinity measures the division of roles between men and women in society. Uncertainty avoidance measures the extent to which members of a culture feel threatened by ambiguous or unknown situations and creates rules and legal systems that try to avoid them. Long-term orientation measures whether people prefer to maintain honorable traditions and norms or favor pragmatic and future-oriented virtues. Finally, indulgence measures the extent to which people try to control their desires and impulses. In indulgence, the control of the country is relatively weak, while in the restriction, it is considered relatively strong.

\section{Control Variables}

As explanatory variables for EM, we use company size, whether the audit firm is a big four or not, return on assets, leverage, sales growth, earnings management by real activities, and as a macroeconomic metric, we use the gross domestic product.

Size, according to $\mathrm{Gu}$, Lee, and Rosett (2005), is one of the most important characteristics of organizations. Larger companies, because they have benefits of scale, maturity, solidity, diversification, and less operational variability, which implies less variability in accruals. We expect a negative relationship between size and EM.

Companies audited by big four audit firms have a lower propensity for EM as big four have more ability to perform audit activities and a greater ability to inhibit accounting manipulation (Haga et al., 2018). We expect a negative relationship between companies audited by big four and discretionary accruals.

According to Prior et al. (2008), more profitable organizations tend to be less involved in EM practices because they have no incentive to manage profit since they already perform well. Also, these companies tend to disclose their economic reality without manipulating values. In addition to the above, we considered that most studies on EM use this variable (ROA) as a control, such as Zang (2011) and Kim et al. (2018). Therefore, we expect a negative 
relationship between ROA and EM.

According to Haga et al. (2018), when trying to explain EM, it requires variables capable of controlling the level of indebtedness of organizations, which reflects the possibility of bankruptcy or financial difficulty. It occurs because companies experiencing financial difficulties tend to minimize EM by actual activities and maximize EM by accruals. Besides, according to $\mathrm{Gu}$ et al. (2005), the degree of leverage gives managers incentives to increase profit by manipulating accruals. We expect a positive relationship between the indebtedness measure and the EM.

The growth of organizations has a positive correlation with accruals, and therefore, according to Gu et al. (2005), the growth of firms represents greater variability in accruals. We expect a positive relationship between the measure of sales growth and EM.

Zand (2011) supports the idea that EM by real activities can be an explanatory variable of EM by accruals. The author states that there is a trade-off between the manipulation of real activities and accruals, in which managers usually "switch" the use of both methods, adjusting the level of manipulation of accruals concerning the level of manipulation of real activities.

This trade-off, according to Zang (2011), is motivated by the costs of each operation, that is, the level of each type of management decreases as a function of its costs and increases as the other way of managing costs. For example, the manager exchanges the EM for real activities for the EM for accruals when their cost increases or when the cost of managing accruals decreases. Also, the cost to manage by real activities or accruals depends on the operating and accounting environment of each company.

Besides, the trade-off happens due to the limitations of each way to manipulate the earnings. Real activity EM can be replaced by accrual management when organizations have limitations on their financial health, investor scrutiny, and their tax consequences. On the other hand, accrual EM is limited to high-quality auditing, accounting for the flexibility of 
organizations, scrutiny of accounting practice after the Sarbanes-Oxley Act, among others (Zang, 2011).

Therefore, we understand that the trade-off between the EM for real activities and accruals happens due to its costs and limitations. Then, when using one of the ways of EM more intensely, there is a tendency to use the other less intensively. Therefore, we expect a negative relationship between the EM by real activities and by accruals.

Gross domestic product (GDP) was the measure used as a macroeconomic factor, as in Haga et al. (2018). According to Mota (2018), firms tend to manage accruals earnings more intensely in periods of economic recession, that is, when GDP is in the process of declining. Therefore, we expect a negative association between the GDP measure and EM.

We initially considered in the models a control variable over IFRS adoption; however, in the final analysis, this variable was excluded from the models due to multicollinearity problems with cultural dimensions.

\section{Empirical Models}

To meet the objective of this research, we operationalized six OLS regression models with correction for robust standard errors and fixed effects control for year and sector, and one model for each dimension of the national culture. We also emphasize that the moderate and moderating variables were standardized in $\mathrm{z}$-score. The general equation is represented by Equation 2 in order to avoid multicollinearity problems.

$$
\begin{aligned}
\text { EM }_{i t}=\beta_{0}+ & \beta_{1} \text { CSR }_{i t}+\beta_{2} \text { CULTURE }_{j}+\beta_{3} \text { CSR }_{i t} * \text { CULTURE }_{j}+\beta_{4} \text { SIZE }_{i t} \\
& +\beta_{5} \text { BF }_{i t}+\beta_{6} \text { ROA }_{i t}+\beta_{7} L E V_{i t}+\beta_{8} \text { SG }_{i t}+\beta_{9} R M_{i t}+\beta_{10} G D P_{j t} \\
& +\sum \text { FixedEffectSector } \\
& +\sum \text { FixedEffectYear }_{i t}+\varepsilon_{i t}
\end{aligned}
$$




\section{EMPIRICAL RESULTS}

\section{Descriptive statistics and correlations}

Table 3 presents the descriptive statistics of the research variables. The EM by accruals variable is in absolute value, so the descriptive statistics consider positive values. The real management, in turn, was operationalized at nominal values and based on the aggregate measure of EM for production costs and discretionary expenses, proposed by Cohen and Zarowin (2008).

\section{[Insert Table 3 here]}

The companies in the sample disclose, on average, 6.04 of the items proposed by Thomson Reuters Eikon on environmental and social issues, considering a scale from 0 to 100 . However, we can explain this low average by the fact that there are about $88 \%$ of companies in the sample that does not disclose any CSR value.

Regarding the Big Four variable $\left(\mathrm{BF}_{\mathrm{it}}\right)$, we observed that a big four audit firm does not audit $61 \%$ of organizations. Companies have, on average, a negative return on assets, and for each $\$ 1.00$ of equity, organizations have $\$ 1.45$ of third-party capital. However, when analyzing the median of the LEV variable, we show that at least $50 \%$ of the companies have resources derived mostly from equity. Corporate revenues grew year over year. However, they showed a high standard deviation, as well as several companies that showed a decrease in their sales from year to year, represented by the negative value of the 25 th percentile. Therefore, we understand that the average value is due to the sales growth of companies located in the 75 th percentile.

Regarding the macroeconomic factor, the countries presented, on average, GDP growth, which we can see in the 25 th, median, and 75 th percentiles. We expected this finding since the G20 countries stand out to economic production.

Among the cultural characteristics of the sample, we highlight the high average and median uncertainty avoidance, which indicates that most countries in the sample are exposed 
to a high tendency to avoid situations involving uncertainty. Regarding the other dimensions, all have both average and median values close to 50 , with a standard deviation close to 20 , which reflects the existence of countries that have high, low, and medium scores on such characteristics.

Table 4 presents the selected sample Pearson correlations. We present the definition of the variables in Appendix I. The sample comprises 19.635 firms to fiscal years ending 2010 to 2017.

\section{[Insert Table 4 here]}

The correlation between social and environmental practices $\left(\mathrm{CSR}_{\mathrm{it}}\right)$ and accounting value manipulation practices $\left(\mathrm{EM}_{\mathrm{it}}\right)$ is negative, which is consistent with the informational view of this relationship. It indicates that organizations that have a socially responsible behavior towards the environment and society, in general, also have conduct in which they value the highest quality of their information, that is, they are less involved in EM practices. We can also observe that the national culture variables present high correlation indices, which indicates the appropriateness of operationalizing a regression for each cultural dimension in order to avoid multicollinearity problems.

\section{Regression analyses}

Table 5 presents the results of the relationship between CSR and EM without the inclusion of cultural factors. We demonstrated these results to empirically reaffirm the theoretical position of the informational view of organizations that engage in social and environmental practices.

\section{[Insert Table 5 here]}

We confirm by these results the negative relationship between CSR and EM already evidenced previously by research such as Bozzolan, Fabrizi, Mallin, and Michelon (2015), Cho and Chun (2015), Martinez-Ferrero et al. (2015), Ko and Kim (2015), Gras-Gil, Manzano, and 
Fernández (2016), and, Hsu and Chen (2017). This result suggests that the sampled companies engage in voluntary disclosure about socially responsible behavior and, at the same time, disclose higher quality accounting information as they engage less in EM and disclose more CSR practices.

The confirmation of this initial premise is important because, from this, we can analyze whether the dimensions of national culture can attenuate or enhance this relationship.

Table 6 presents the results of model 2, estimated through robust standard error OLS regression. Each column from 1 to 6 refers to a national culture dimension, operationalized separately because of the multicollinearity between them.

\section{[Insert Table 6 here]}

Similar to Bozzolan et al. (2015), we use the standardized coefficient of the variables to be able to compare the results of each column. In order to investigate H1, we analyzed whether the dimension of power distance, as it represents societies with higher hierarchy and authoritarianism, would influence managers to manage earnings more intensely, since the high hierarchy implies subordinates less questioning about activities' superiors, as pointed out by Paredes and Wheatley (2017). It leads us to support the hypothesis that in this cultural context, organizations behaved in a "less" informational way (the positive relationship between CSR and EM).

However, in column 1, we observed that the interaction between CSR business practices and power distance $\left(\mathrm{CSR}_{\mathrm{it}} * \mathrm{PD}_{\mathrm{j}}\right)$ was negatively related to $\mathrm{EM}$, which reveals that companies, even exposed to a high cultural distance power, tend to use socially responsible practices, motivated by informational conduct, because while engaging in social and environmental actions also manipulates the earnings with less intensity. Economically, we found that companies engaged in CSR practices and exposed to high power distances have, on average, a $20.37 \%$ reduction in EM (-0.0163: 0.08). To calculate the economic coefficient, we divided the 
statistical coefficient of the independent variable $\left(\mathrm{CSR}_{\mathrm{it}} * \mathrm{CULTURE}_{\mathrm{j}}\right)$ by the average of the dependent variable $\left(\mathrm{EM}_{\mathrm{it}}\right)$. Thus, we found that the power distance enhances the negative relationship between CSR and EM, contrary to the expected result.

To investigate $\mathrm{H} 2$, we analyze whether the cultural tendency towards individualism prompts organizations and their managers to conduct their decisions in a "less" informational way than societies with collectivist tendencies while considering that this cultural tendency may induce opportunistic behavior by reflecting on greater engagement in CSR and greater manipulation of earnings. In column 2, we noticed that the interaction between the CSR variable and individualism $\left(\mathrm{CSR}_{\mathrm{it}} * \mathrm{INDI}_{\mathrm{j}}\right)$ was positive and statistically significant, which is in line with the premise that the cultural tendency towards individualism may attenuate the negative relationship between CSR and EM, or even make it positive. Based on the economic analysis of the coefficients, we realize that companies engaged in CSR and exposed to the cultural tendency of individualism tend to increase, in medium, the manage earnings about $8.12 \%$ (0.0065: 0.08).

Concerning H3, we analyzed whether the masculinity dimension is related to less informational or still opportunistic business behavior (the positive relationship between CSR and EM). In column 3, we noticed that the interaction between CSR actions and masculinity $\left(\mathrm{CSR}_{\mathrm{it}} * \mathrm{MAS}_{\mathrm{j}}\right)$ was positive, which is in line with the premise that masculinity may attenuate the negative relationship between CSR and EM, or even become positive. We analyze the coefficients economically and note that companies engaged in social and environmental practices, and exposed to the cultural tendency of masculinity, tend to manage earnings more, in medium, about $14.50 \%$ (0.0116: 0.08$)$. It shows that masculinity makes managers likely to conduct their business "less informationally" than in culturally feminine countries.

Our evidence corroborates the premise that masculinity is responsible for inducing managers to behave opportunistically about their CSR practices because CSR engagement is 
related to higher rates of EM. The opportunistic view of CSR practices justifies the positive relationship with EM, assuming that organizations engage in CSR practices to mask opportunistic practices, such as EM. In this sense, CSR practices would be a way for organizations not to attract the attention of their stakeholders and to appear to be more transparent companies (Prior et al., 2008).

In order to verify $\mathrm{H} 4$, we analyzed whether the cultural tendency towards uncertainty avoidance can prompt organizations and their managers to disclose corporate social responsibility practices, motivated by information transparency (informational behavior). We noticed that in column 4 , the interaction between CSR and UAI $\left(\mathrm{CSR}_{\mathrm{it}} * \mathrm{UAI}_{\mathrm{j}}\right)$ had a negative and significant coefficient, which reveals that companies continue to invest in CSR and to manipulate their earnings with less intensity, in contexts where societies tend to avoid uncertain situations. We analyzed the coefficients economically and found that companies engaged in CSR and exposed to the cultural context of high uncertainty avoidance tend to reduce EM by about $14.37 \%(-0.0115: 0.08)$.

The fifth dimension of national culture is tested by $\mathrm{H} 5$, in which we analyze whether long-term orientation contributes to organizations valuing the transparency and quality of accounting information (informational conduct). For this reason, we support H5 that long-term companies, because they value the continuity of their business and plan their long-term goals, are less involved in manipulating earnings and more in CSR practices. In column 6, we noticed that the interaction between CSR and long-term orientation showed a negative coefficient, as expected, but not statistically significant, revealing that this cultural tendency does not influence the relationship between socially responsible practices and EM.

Finally, to test H6, we analyze whether more indulgent societies, because they represent conditions of few restrictions and more freedom (Hofstede, 2011), are related to greater manipulation of earnings, since, in this cultural context, the tendency is that there is more room 
for o the opportunistic behavior of managers. In column 6 , we identified that the interaction between the CSR variable and indulgence $\left(\mathrm{CSR}_{\mathrm{it}} * \mathrm{INDU}_{\mathrm{j}}\right)$ showed a positive and significant coefficient, which is consistent with the understanding that indulgence may attenuate the negative relationship between CSR and EM, or even to become positive, thus representing the opportunistic behavior of managers. Economically, we observe that companies engaged in CSR and exposed to the highly indulgent cultural context tend to increase EM by $12.50 \%(0.0100$ : $0.08)$.

Among the six cultural dimensions of Hofstede et al. (2010), five seems to influence the relationship between socially responsible behavior of organizations and the opportunistic practice of EM. We verified from the standardized coefficient that the cultural dimension that most influences this relationship (CSR and EM) is the power distance, which, contrary to expectations, prompts organizations to informational behavior (the negative relationship between CSR and EM). On the other hand, the second cultural dimension that showed the greatest influence was the masculinity, which, as expected, instigates organizations to opportunistic behavior (the positive relationship between CSR and EM).

\section{Robustness tests}

To strengthen our results, we repeated our tests using a subsample of companies selected by Propensity Score Matching, which we select similarly among companies that do or do not have any CSR practice. As our sample is $88 \%$ made up of organizations that do not report any social or environmental practices, we used the Propensity Score Matching as a method to equate companies that have socially responsible action with the same number of companies that do not. We grouped these companies by industry and similar size.

In this additional test, our sample includes 18,714 observations from companies that disclose CSR practices, and 18,714 observations from companies that do not disclose, totaling 37,418 observations. Table 7 presents these results. 


\section{[Insert Table 7 here]}

We confirm our main results through Propensity Score Matching, about the influence of the dimensions of power distance, individualism, masculinity, and uncertainty avoidance. We realize, through the standardized coefficient, that the greatest influence on the relationship between CSR and EM practices is from the dimension of masculinity, followed by the distance of power, indulgence, and individualism.

The influence of the power distance on the relationship between CSR and EM, however, differs from what we expected, as this cultural tendency influenced informational rather than opportunistic behavior. We based our argument on Han et al. (2010), Gray et al. (2015), and Paredes and Wheatley (2017), who empirically evidenced that the power distance induced organizations to the largest EM. Based on these studies, we argue that power distance characterizes societies in which managers are more likely to abuse their authority to achieve goals (Gray et al., 2015), and to consider that their subordinates are less likely to report related dubious practices to their superiors (Ugrin et al., 2017). Therefore, we expected that the distance of power would influence the opportunistic behavior of managers. However, our results show that even in a cultural dimension of high distance from power, managers seem to care for transparency (higher CSR) and quality of information (lower EM).

Our results confirm the expected influence of individualism, masculinity, and indulgence. In these cultural trends, organizations seem to be managing their earnings more intensely and disseminating more socially responsible practices, which supports the opportunistic view of CSR practices, designed to hide opportunistic behavior and not attract the attention of stakeholders (Kim et al., 2012). In general, individualism, masculinity, and indulgence seem to be cultural dimensions responsible for influencing organizations and their managers to disclose more social and environmental practices and to manipulate accounting information with less intensity. 
This evidence suggests a possible explanation for previous research that found a positive relationship between CSR and EM (Muttakin et al., 2015; Carey et al., 2017; Patro \& Pattanayak, 2017; Gavana et al., 2017; Kim et al., 2018; Jordaan et al., 2018) by highlighting which dimensions of national culture influence the behavior of organizations concerning transparency and quality of information. Moreover, the literature review showed the need to justify the ambiguity of the results on the relationship between CRS and EM as to why, in a given context, CSR seems to be linked to the lowest EM, while in others, it is related to the higher EM. Therefore, this research sheds light on individualism, masculinity, and indulgence as cultural characteristics capable of inducing managers to behave opportunistically concerning their CSR practices.

We believe that this discussion may generate evidence about the effect of national culture on the relationship between CSR and EM, as it shows that a certain cultural characteristic (distance from power) can influence organizations to disclose more transparent and higher quality information, while societies with individualistic, masculine and indulgent behaviors can contribute to the opportunistic behavior of managers and/or companies, both due to the greater EM and the greater engagement in social and environmental practices.

We empirically confirm the theoretical assumptions highlighted by Martínez-Ferrero and García-Sánchez (2015), García-Sánchez and García-Meca (2017) and Kim et al. (2018), who suggested that possible advances in research on the relationship between CSR and EM might consider the effects of country-level factors, such as cultural ones. Besides, we contributed by expanding the previous findings of Martínez-Ferrero and García-Sánchez (2015), Muttakin et al. (2015), Bozzolan et al. (2015), Martinez-Ferrero et al. (2015), Ko and Kim (2015), Gras-Gil et al. (2016), Gavana et al. (2017), Hsu and Chen (2017), Patro and Pattanayak (2017), Jordaan et al. (2018) and Kim et al. (2018), which showed divergent relations between CSR and EM but did not seek explanations about factors that could induce these different findings. 


\section{SUMMARY AND CONCLUSIONS}

We examined whether national culture can be responsible for helping to explain ambiguous results on the relationship between CSR and EM practices across countries. Our hypotheses argue that the cultural context of each country can lead to a positive relationship between CSR and EM, which represents the use of CSR only as a way to improve the company's image vis-à-vis the market, with a possible bias to "hide" practices EM (opportunistic approach to CSR). On the other hand, the country's culture may induce a negative relationship between CSR and EM, which would indicate that socially responsible companies would also have more transparent, reliable, and ultimately higher quality accounting earnings (CSR informational approach).

Our results support the premise that the cultural dimensions of individualism, masculinity, and indulgence influence the relationship between CSR and EM, suggesting that future research should include these factors at the country-level in their analysis. More specifically, we demonstrate that individualistic, male and indulgent organizations are prone to opportunistic behavior, which can guide organizations in trying to mitigate the cultural influence of their country by inserting control mechanisms aimed at both EM and CSR practices, to ensure that the information disclosed is transparent and of the highest quality. Interestingly, our results have shown that power distance influences the negative relationship between EM and CSR, which helps guide organizations exposed to this cultural context about the possibility of using fewer control mechanisms, as their managers are culturally prone to generate more transparent (more CSR) and higher quality (less EM) information.

We understand that our results may also be useful to investors and shareholders, who may pay attention to the cultural characteristics of the countries in which organizations operate when deciding on their investments. These information users may look more carefully at contexts of high individualism, masculinity, and indulgence (prone to opportunistic behavior). 
Overall, the empirical evidence is consistent with the assumptions that national culture dimensions influence the relationship between EM and CSR. After testing with a subsample of companies that engage or not in social and environmental practices that are similar in size and belonging to the same industry, we found the same results.

However, there are limitations, since this is the first research to which we are aware that investigated the moderating role of national culture in the relationship between CSR and EM, and from the perspective of cultural influence approach, therefore, other investigations are still necessary to ascertain our findings. 
Appendix I

Definitions of Variables

Variable

Definition

Corporate Social Responsibility

- Social Pillar

The social pillar measures a company's capacity to generate trust and loyalty with its workforce, customers, and society, through its use of best management practices. It is a reflection of the company's reputation and the health of its license to operate, which are key factors in determining its ability to generate long term shareholder value.

The environmental pillar measures a company's impact on living and nonliving natural systems, including the air, land, and water, as well as complete

- Environmental Pillar ecosystems. It reflects how well a company uses best management practices to avoid environmental risks and capitalize on environmental opportunities in order to generate long term shareholder value.

Earnings Management (EM) Discretionary accruals, estimated by the Kothari, Leone, and Wasley

Model (2005) cross-section by year, sector, and country. Operationalized in absolute value.

Power Distance (PD) It ranges from 0 to 100 , the closer to 100 means there is more power distance in the country.

Individualism (INDI) It ranges from 0 to 100 , the closer to 100 means there is greater individualism in the country.

Masculinity (MAS) It ranges from 0 to 100, the closer to 100 means there is greater masculinity in the country.

Uncertainty Avoidance (UAI) It ranges from 0 to 100 , the closer to 100 means that there is greater uncertainty avoidance in the country.

Long Term Orientation (LT) It ranges from 0 to 100 , the closer to 100 means that there is a greater longterm orientation in the country.

Indulgence (INDU) It ranges from 0 to 100 , the closer to 100 means there is greater indulgence in the country.

\begin{tabular}{ll}
\hline Size (SIZE) & Natural log of total sales. \\
\hline Big Four (BF) & Categorical variable: $1=$ audited by big four; 0 otherwise. \\
\hline Return on Assets (ROA) & Net income before extraordinary items at t-1 divided by total assets at t-1. \\
\hline Leverage (LEV) & Total liabilities in t divided by total equity in t. \\
\hline Sales Grown (SG) & $\begin{array}{l}\text { Percentage change in sales, calculated by sales at t minus sales at t-1, divided } \\
\text { by sales at t-1. }\end{array}$ \\
\hline Real Management (RM) & Calculated by Roychowdhury's model (2006):
\end{tabular}

- Production costs:

$$
\frac{P C_{i t}}{A_{i t-1}}=\alpha_{0}+\alpha_{1} \frac{1}{A_{i t-1}}+\beta_{1} \frac{S_{i t}}{A_{i t-1}}+\beta_{2} \frac{\Delta \mathrm{S}_{i t}}{A_{i t-1}}+\beta_{3} \frac{\Delta \mathrm{S}_{i t-1}}{A_{i t-1}}+\varepsilon_{i t}
$$

- Discretionary Expenses:

$$
\frac{D D_{i t}}{A_{i t-1}}=\alpha_{0}+\alpha_{1} \frac{1}{A_{i t-1}}+\beta \frac{S_{i t-1}}{A_{i t-1}}+\varepsilon_{i t}
$$

We use the aggregate measure proposed by Cohen and Zarowin (2008), calculated by the sum of the residuals of the discretionary expense equation (multiplied by -1) and the residuals of the production cost equation.

Gross Domestic Product (GDP) \% annual growth, available on the World Bank website (2018).

Note: We do not consider Roychowdhury's (2006) operating cash flow model because, according to Zang (2011), the net effect of abnormal cash flow behavior from operations is ambiguous as to the expected sign of discretionary cash decisions of organizations. 


\section{References}

Ali, W., Frynas, J. G., and Mahmood, Z. 2017. Determinants of corporate social responsibility (CSR) disclosure in developed and developing countries: A literature review. Corporate Social Responsibility, \& Environmental Management, 24(4): 273294.

Bozzolan, S., Fabrizi, M., Mallin, C. A., and Michelon, G. 2015. Corporate social responsibility and earnings quality: International evidence. The International Journal of Accounting, 50(4): 361-396.

Brooks, C., and Oikonomou, I. 2018. The effects of environmental, social, and governance disclosures and performance on firm value: A review of the literature in accounting and finance. The British Accounting Review, 50(1): 1-15.

Carey, P., Liu, L., and Qu, W. 2017. Voluntary corporate social responsibility reporting and financial statement auditing in China. Journal of Contemporary Accounting \& Economics, 13(3): 244-262.

Chih, H. L., Shen, C. H., and Kang, F. C. 2008. Corporate social responsibility, investor protection, and earnings management: Some international evidence. Journal of business ethics, 79(1-2): 179-198.

Chollet, P., and Sandwidi, B. W. (2018). CSR engagement and financial risk: A virtuous circle? International evidence. Global Finance Journal, 38: 65-81.

Cohen, D. A., and Zarowin, P. 2008. Economic consequences of real and accrual-based earnings management activities. Leonard Ster School of Business \& New York University, Working Paper.

Davis, K. (1973). The case for and against business assumption of social responsibilities. Academy of Management Journal, 16(2): 312-322.

Dechow, P. M., and Dichev, I. D. 2002. The quality of accruals and earnings: The role of accrual estimation errors. The accounting review, 77(s-1): 35-59.

Desender, K. A., Castro, C. E., and De León, S. A. E. 2011. Earnings management and cultural values. American Journal of Economics and Sociology, 70(3): 639-670.

Doupnik, T. S. 2008. Influence of culture on earnings management: A note. Abacus, 44(3): 317340.

Esteban, V. A., Villardón, M. P. G., and Sanchez, I. M. G. (2017). Cultural values on CSR patterns and evolution: A study from the biplot representation. Ecological indicators, 81: 18-29.

García-Sánchez, I. M., and García-Meca, E. 2017. CSR engagement and earnings quality in banks. The moderating role of institutional factors. Corporate Social Responsibility \& Environmental Management, 24(2): 145-158.

Gargouri, R. M., Shabou, R., and Francoeur, C. 2010. The relationship between corporate social performance and earnings management. Canadian Journal of Administrative Sciences/Revue Canadienne Des Sciences De l'Administration, 27(4): 320-334.

Gavana, G., Gottardo, P., and Moisello, A. 2017. Earnings management and CSR disclosure. Family vs. non-family firms. Sustainability, 9(12): 2327.

Gras-Gil, E., Manzano, M. P., and Fernández, J. H. 2016. Investigating the relationship between corporate social responsibility and earnings management: Evidence from Spain. $B R Q$ Business Research Quarterly, 19(4): 289-299.

Gray, S. J. 1988. Towards a theory of cultural influence on the development of accounting systems internationally. Abacus, 24(1): 1-15.

Gray, S. J., Kang, T., Lin, Z., and Tang, Q. (2015). Earnings management in Europe post IFRS: do cultural influences persist?. Management International Review, 55(6): 827-856. 
Gu, Z., Lee, C. W. J., and Rosett, J. G. 2005. What determines the variability of accounting accruals?. Review of Quantitative Finance \& Accounting, 24(3): 313-334.

Haga, J., Ittonen, K., Tronnes, P. C., and Wong, L. 2018. Is earnings management sensitive to discount rates?. Journal of Accounting Literature, 41: 75-88.

Han, S., Kang, T., Salter, S., and Yoo, Y. K. 2010. A cross-country study on the effects of national culture on earnings management. Journal of International Business Studies, 41(1): 123-141.

Hofstede, G. 1991. Cultures and Organizations: Software of the Mind. McGraw-Hill Book Company London.

Hofstede, G. 2011. Dimensionalizing cultures: The Hofstede model in context. Online readings in psychology \& culture, 2(1): 8.

Hofstede, G. 2018. The 6-D model of national culture. Available in: <https://geerthofstede.com>. Access on: 24 August 2018.

Hofstede, G., Hofstede, G. J., and Minkov, M. 2010. Cultures and organizations: software of the mind. McGraw-Hill Book Company London.

Hofstede. G. 1980. Culture's consequences: International differences in work-related values. Sage.

Hsu, F. J., and Chen, Y. C. 2018. Human behavior analysis under financial information science: Evidence from corporate social responsibility. Library Hi Tech, 36(4): 685-704.

Jordaan, L. A., De Klerk, M., and Villiers, C. J. 2018. Corporate social responsibility and earnings management of South African companies. South African Journal of Economic and Management Sciences, 21(1): 1-13.

Kim, S. H., Udawatte, P., and Yin, J. 2018. The Effects of Corporate Social Responsibility on Real and Accrual-based Earnings Management: Evidence from China. Australian Accounting Review. 29 (3): 452-454.

Kim, Y., Park, M. S., and Wier, B. 2012. Is earnings quality associated with corporate social responsibility?. The accounting review, 87(3): 761-796.

Klann, R. C. 2011. Gerenciamento de resultados: análise comparativa de empresas brasileiras e inglesas antes e após a adoção das IFRS. 2011. $371 \mathrm{f}$ (Doctoral dissertation, Tese (Doutorado em Ciências Contábeis e Administração) - Programa de Pós-Graduação em Ciências Contábeis da Universidade Regional de Blumenau, Blumenau).

Ko, W. S., and Kim, S. S. 2015. Corporate Earnings Quality in the Socially Responsible Investing Firms. International Information Institute (Tokyo). Information, 18(5B): 1905.

Kothari, S. P., Leone, A. J., and Wasley, C. E. 2005. Performance matched discretionary accrual measures. Journal of accounting \& economics, 39(1): 163-197.

Lee, J. H., Byun, H. S., and Park, K. S. 2018. Product market competition and corporate social responsibility activities: Perspectives from an emerging economy. Pacific-Basin Finance Journal, 49: 60-80.

Martinez-Ferrero, J., and García-Sánchez, I. M. 2015. Is corporate social responsibility an entrenchment strategy? Evidence in stakeholder protection environments. Review of Managerial Science, 9(1): 89-114.

Martínez-Ferrero, J., Gallego-Álvarez, I., and García-Sánchez, I. M. (2015). A bidirectional analysis of earnings management and corporate social responsibility: the moderating effect of stakeholder and investor protection. Australian Accounting Review, 25(4): 359-371.

Mota, R. H. G. 2018. A influência dos ciclos econômicos no gerenciamento de resultados contábeis. Tese (Doutorado em Ciências Contábeis) — Programa Multi Institucional e Inter-Regional de Pós-Graduação em Ciências Contábeis, Universidade de Brasília, 
Universidade Federal da Paraíba, Universidade Federal do Rio Grande do Norte, Natal, $223 f$.

Muttakin, M. B., Khan, A., and Azim, M. I. 2015. Corporate social responsibility disclosures and earnings quality: Are they a reflection of managers' opportunistic behavior?. Managerial Auditing Journal, 30(3): 277-298.

Nabar, S., and Boonlert-U-Thai, K. K. 2007. Earnings management, investor protection, and national culture. Journal of International Accounting Research, 6(2): 35-54.

Paredes, A. A. P, and Wheatley, C. 2017. The influence of culture on real earnings management. International Journal of Emerging Markets, 12(1): 38-57.

Patro, B., and Pattanayak, J. K. (2017). Corporate Governance as a Moderating Variable for Identifying the Relationship Between CSR and Earnings Management: A Study of Listed Indian Mining Firms. Prabandhan: Indian Journal of Management, 10(10): 2440.

Prior, D., Surroca, J., and Tribó, J. A. 2008. Are socially responsible managers really ethical? Exploring the relationship between earnings management and corporate social responsibility. Corporate Governance: An International Review, 16(3): 160-177.

Roychowdhury, S. 2006. Earnings management through real activities manipulation. Journal of accounting \& economics, 42(3): 335-370.

Salewski, M., and Zülch, H. 2014. The Association between corporate social responsibility and earnings quality-evidence from European blue chips.

Taylor, E. Z., and Curtis, M. B. 2013. Whistleblowing in audit firms: Organizational response and power distance. Behavioral Research in Accounting, 25(2): 21-43.

Ugrin, J. C., Mason, T. W., and Emley, A. 2017. Culture's consequence: The relationship between income-increasing earnings management and IAS/IFRS adoption across cultures. Advances in accounting, 37: 140-151.

Zang, A. Y. 2011. Evidence on the trade-off between real activities manipulation and accrualbased earnings management. The Accounting Review, 87(2): 675-703. 
Table 1

Sample selection and distribution

\begin{tabular}{|c|c|c|}
\hline & Firms & $\%$ \\
\hline Population & 37.397 & 100 \\
\hline (-) Without information & 16.675 & 45 \\
\hline (-) Financial Sector & 693 & 2 \\
\hline (-) Not representative countries & 145 & 0 \\
\hline (-) Countries without any CSR information & 249 & 1 \\
\hline Total & 19.635 & 53 \\
\hline \multicolumn{3}{|l|}{ Panel B - Breakdown of observations by country } \\
\hline Countries & Firms & $\%$ \\
\hline Germany & 463 & 2,4 \\
\hline Argentina & 72 & 0,4 \\
\hline Australia & 919 & 4,7 \\
\hline Belgium & 91 & 0,5 \\
\hline Brazil & 258 & 1,3 \\
\hline Canada & 800 & 4,1 \\
\hline China & 3.504 & 17,8 \\
\hline South Korea & 1.615 & 8,2 \\
\hline Denmark & 95 & 0,5 \\
\hline Spain & 129 & 0,7 \\
\hline USA & 3.382 & 17,2 \\
\hline Finland & 108 & 0,6 \\
\hline France & 490 & 2,5 \\
\hline Greece & 195 & 1,0 \\
\hline Netherlands & 105 & 0,5 \\
\hline India & 2.174 & 11,1 \\
\hline Indonesia & 380 & 1,9 \\
\hline Ireland & 55 & 0,3 \\
\hline Italy & 199 & 1,0 \\
\hline Japan & 3.261 & 16,6 \\
\hline Mexico & 107 & 0,5 \\
\hline Poland & 410 & 2,1 \\
\hline Russia & 525 & 2,7 \\
\hline Turkey & 298 & 1,5 \\
\hline Amostra total & 19.635 & 100 \\
\hline \multicolumn{3}{|c|}{ Panel C - Breakdown of observations by industry } \\
\hline Industries & Firms & $\%$ \\
\hline Consumer Discretionary & 3.777 & 19,2 \\
\hline Consumer Staples & 1.382 & 7,0 \\
\hline Energy & 942 & 4,8 \\
\hline Health Care & 1.632 & 8,3 \\
\hline Industrials & 4.123 & 21,0 \\
\hline Information Tecgnology & 3.130 & 15,9 \\
\hline Materials & 2.611 & 13,3 \\
\hline Others & 630 & 3,2 \\
\hline Real Estate & 772 & 3,9 \\
\hline Telecommunication Services & 184 & 0,9 \\
\hline Utilities & 452 & 2,3 \\
\hline Total & 19.635 & 100 \\
\hline
\end{tabular}

Note: Non-representative countries were those with less than 50 companies; The sectors classification by the GICS (Global Industry Classification Standard). 
Table 1

Observations with and without CSR score by year

\begin{tabular}{cccccccc}
\hline Year & With CSR & \% Obs & \% Change & Without CSR & \% Obs & \% Change & Total \\
\hline 2010 & 1.704 & $8,68 \%$ & & 17.931 & $91,32 \%$ & & 19.635 \\
2011 & 1.946 & $9,91 \%$ & $12,4 \%$ & 17.689 & $90,09 \%$ & $-1,4 \%$ & 19.635 \\
2012 & 2.028 & $10,33 \%$ & $4,0 \%$ & 17.607 & $89,67 \%$ & $-0,5 \%$ & 19.635 \\
2013 & 2.108 & $10,74 \%$ & $3,8 \%$ & 17.527 & $89,26 \%$ & $-0,5 \%$ & 19.635 \\
2014 & 2.215 & $11,28 \%$ & $4,8 \%$ & 17.420 & $88,72 \%$ & $-0,6 \%$ & 19.635 \\
2015 & 2.450 & $12,48 \%$ & $9,6 \%$ & 17.185 & $87,52 \%$ & $-1,4 \%$ & 19.635 \\
2016 & 2.986 & $15,21 \%$ & $18,0 \%$ & 16.649 & $84,79 \%$ & $-3,2 \%$ & 19.635 \\
2017 & 3.277 & $16,69 \%$ & $8,9 \%$ & 16.358 & $83,31 \%$ & $-1,8 \%$ & 19.635 \\
Total & $\mathbf{1 8 . 7 1 4}$ & $\mathbf{1 1 , 9 1 \%}$ & & $\mathbf{1 3 8 . 3 6 6}$ & $\mathbf{8 8 , 0 9 \%}$ & & $\mathbf{1 5 7 . 0 8 0}$ \\
\hline
\end{tabular}

Table 3

Descriptive Statistic

\begin{tabular}{|c|c|c|c|c|c|c|c|c|c|}
\hline \multicolumn{10}{|c|}{ Panel A - Descriptive statistics } \\
\hline & $\mathbf{E M}_{\mathrm{it}}$ & $\mathbf{C S R}_{\text {it }}$ & SIZE $_{\text {it }}$ & $\mathbf{B F}_{\text {it }}$ & $\mathbf{R O A}_{\text {it }-1}$ & $\mathbf{L E V}_{\text {it }}$ & $\mathbf{S G}_{\text {it }}$ & $\mathbf{R M}_{\text {it }}$ & $\mathbf{G D P}_{\mathrm{jt}}$ \\
\hline Mean & 0,08 & 6,04 & 18,54 & 0,39 & $-0,06$ & 1,45 & 0,27 & 0,01 & 2,85 \\
\hline SD & 0,12 & 17,99 & 2,70 & 0,48 & 0,44 & 3,24 & 1,35 & 0,37 & 3,51 \\
\hline Perc 25 & 0,01 & 0 & 17,27 & 0 & $-0,01$ & 0,37 & $-0,07$ & $-0,13$ & 1,24 \\
\hline Median & 0,04 & 0 & 18,77 & 0 & 0,02 & 0,90 & 0,05 & 0,02 & 2,28 \\
\hline Perc 75 & 0,09 & 0 & 20,21 & 1 & 0,06 & 1,86 & 0,21 & 0,18 & 4,34 \\
\hline \multicolumn{10}{|c|}{157.080 observations } \\
\hline \multicolumn{10}{|c|}{ Panel B - Descriptive statistics of cultural variables } \\
\hline & PD & & $\mathbf{I N D I}_{\mathbf{j}}$ & $\mathbf{M A S}_{\mathbf{j}}$ & & $\mathbf{U A} \mathbf{I}_{\mathbf{j}}$ & & & INDU $_{\mathbf{j}}$ \\
\hline Mean & 56 & & 54 & 52 & & 68 & & & 50 \\
\hline SD & 19 & & 22 & 18 & & 24 & & & 19 \\
\hline Perc 25 & 38 & & 37 & 42 & & 48 & & & 34 \\
\hline Median & 58 & & 55 & 55 & & 75 & & & 49 \\
\hline Perc 75 & 68 & & 74 & 65 & & 86 & & & 66 \\
\hline
\end{tabular}

Variables are defined in Appendix I.

Table 4

Correlation matrix

\begin{tabular}{|c|c|c|c|c|c|c|c|c|}
\hline & $\mathbf{E M}_{\text {it }}$ & $\mathrm{CSR}_{\text {it }}$ & $\mathbf{P D}_{\mathbf{j}}$ & $\mathbf{I N D I}_{\mathbf{j}}$ & $\mathbf{M A S}_{\mathrm{j}}$ & $\mathbf{U A I}_{\mathbf{j}}$ & $\mathbf{L} \mathbf{T}_{\mathbf{j}}$ & INDU $_{\mathbf{j}}$ \\
\hline $\mathbf{E M}_{\text {it }}$ & 1 & & & & & & & \\
\hline CSR $_{\text {it }}$ & $-0.0687 *$ & 1 & & & & & & \\
\hline $\mathbf{P D}_{\mathrm{j}}$ & $-0.0328 *$ & $-0.2077 *$ & 1 & & & & & \\
\hline $\mathbf{I N D I}_{\mathbf{j}}$ & $0.1459 *$ & $0.2086^{*}$ & $-0.7786 *$ & 1 & & & & \\
\hline $\mathbf{M A S}_{\mathbf{j}}$ & $-0.1050 *$ & $-0.0160 *$ & $-0.1237 *$ & $0.0117 *$ & 1 & & & \\
\hline $\mathbf{U A} \mathbf{I}_{\mathbf{j}}$ & $-0.1114^{*}$ & $0.0186^{*}$ & $-0.1407 *$ & $-0.0712 *$ & $0.2084 *$ & 1 & & \\
\hline $\mathbf{L} \mathbf{T}_{\mathbf{j}}$ & $-0.1844^{*}$ & $-0.1568 *$ & $0.5040 *$ & $-0.8182 *$ & $0.2331 *$ & $0.3130 *$ & 1 & \\
\hline $\mathbf{I N D U}_{\mathbf{j}}$ & $0.1044 *$ & $0.2235^{*}$ & $-0.8247 *$ & $0.8276^{*}$ & $0.0059 *$ & $0.0079 *$ & $-0.7537 *$ & 1 \\
\hline
\end{tabular}

* indicate statistical significance at the 0.05 level. Variables are defined in Appendix I. 
Table 5

Results of the relationship between CSR and EM

\begin{tabular}{|c|c|c|}
\hline & $\begin{array}{c}\mathbf{E M}_{\mathrm{it}} \\
\beta \\
(\mathrm{OLS}) \\
\end{array}$ & $\begin{array}{c}\mathbf{E M}_{\mathrm{it}} \\
\beta \\
\text { (Propensity Score Matching) } \\
\end{array}$ \\
\hline Constant & $\begin{array}{c}- \\
(29.23)\end{array}$ & $(13.76)$ \\
\hline $\mathrm{CSR}_{\text {it }}$ & $\begin{array}{c}-0.0048208 * * \\
(-1.96)\end{array}$ & $\begin{array}{c}-0.060451 * * * \\
(-5.36)\end{array}$ \\
\hline $\mathrm{SIZE}_{\mathrm{it}}$ & $\begin{array}{c}-0.1069869 * * * \\
(-25.33)\end{array}$ & $\begin{array}{c}-0.0443983 * * * \\
(-6.81)\end{array}$ \\
\hline $\mathrm{BF}_{\mathrm{it}}$ & $\begin{array}{c}-0.0111168 * * * \\
(-4.13)\end{array}$ & $\begin{array}{c}0.0265202 * * * \\
(5.12)\end{array}$ \\
\hline $\mathrm{ROA}_{\mathrm{it}-1}$ & $\begin{array}{c}-0.0654031 * * * \\
(-11.97)\end{array}$ & $\begin{array}{c}-0.0164842 \\
(-1.48)\end{array}$ \\
\hline $\mathrm{LEV}_{\text {it }}$ & $\begin{array}{c}0.0024289 \\
(0.79)\end{array}$ & $\begin{array}{c}-0.0214181 * * * \\
(-2.95)\end{array}$ \\
\hline $\mathrm{SG}_{\mathrm{it}}$ & $\begin{array}{c}0.0491153 * * * \\
(11.41)\end{array}$ & $\begin{array}{c}0.0630191 * * * \\
(8.79)\end{array}$ \\
\hline $\mathrm{RM}_{\mathrm{it}}$ & $\begin{array}{c}0.0621639 * * * \\
(19.68)\end{array}$ & $\begin{array}{c}0.1122816^{* * * *} \\
(18.24)\end{array}$ \\
\hline $\mathrm{GDP}_{\mathrm{it}}$ & $\begin{array}{c}-0.0346727 * * * \\
(-6.15)\end{array}$ & $\begin{array}{c}0.0209884 * * * \\
(4.29)\end{array}$ \\
\hline Treat & $\begin{array}{l}- \\
-\end{array}$ & $\begin{array}{c}0.0333712^{* * * *} \\
2.88\end{array}$ \\
\hline $\begin{array}{l}\text { Prob > F } \\
\text { Squared R } \\
\text { Durbin Watson } \\
\text { VIF maximum } \\
\text { Year fixed effects } \\
\text { Industry fixed effects } \\
\text { Country fixed effects } \\
\text { Observations } \\
\end{array}$ & $\begin{array}{c}0.0000 * * * \\
15.81 \% \\
1.860555 \\
6.08 \\
\text { Yes } \\
\text { Yes } \\
\text { Yes } \\
157,080 \\
\end{array}$ & $\begin{array}{c}0.0000 * * * \\
2.46 \% \\
0.466 \\
4.45 \\
\text { No } \\
\text { No } \\
\text { No } \\
37,428 \\
\end{array}$ \\
\hline
\end{tabular}


Table 6

Results of influence of national culture on the relationship between CSR and EM

\begin{tabular}{|c|c|c|c|c|c|c|}
\hline & $\begin{array}{c}\mathbf{E M}_{\mathrm{it}} \\
\beta \\
(1) \\
\end{array}$ & $\begin{array}{c}\mathbf{E M}_{\mathrm{it}} \\
\beta \\
(2) \\
\end{array}$ & $\begin{array}{c}\mathbf{E M}_{\mathrm{it}} \\
\beta \\
(3) \\
\end{array}$ & $\begin{array}{c}\mathbf{E M}_{\text {it }} \\
\beta \\
(4) \\
\end{array}$ & $\begin{array}{c}\mathbf{E M}_{\text {it }} \\
\beta \\
(5) \\
\end{array}$ & $\begin{array}{c}\mathbf{E M}_{\text {it }} \\
\beta \\
(6) \\
\end{array}$ \\
\hline Constant & $\begin{array}{c}- \\
(40.76)\end{array}$ & $\begin{array}{c}- \\
(17.16)\end{array}$ & $\overline{(44.56)}$ & $\begin{array}{c}- \\
(51.30)\end{array}$ & $\begin{array}{c}- \\
(37.95)\end{array}$ & $\begin{array}{c}- \\
(18.63)\end{array}$ \\
\hline $\mathrm{CSR}_{\mathrm{it}}$ & $\begin{array}{c}0.0003 \\
(0.16)\end{array}$ & $\begin{array}{c}-0.0190 * * * \\
(-8.93)\end{array}$ & $\begin{array}{c}0.0087 * * * \\
(3.68)\end{array}$ & $\begin{array}{r}-0.0027 \\
(-1.11)\end{array}$ & $\begin{array}{c}-0.0243 * * * \\
(-11.46)\end{array}$ & $\begin{array}{c}-0.0134 * * * \\
(-6.53)\end{array}$ \\
\hline $\mathrm{PD}_{\mathrm{j}}$ & $\begin{array}{c}-0.0372 * * * \\
(-8.97)\end{array}$ & & & & & \\
\hline $\mathbf{C S R}_{\mathrm{it}} * \mathbf{P D}_{\mathrm{j}}$ & $\begin{array}{c}-0.0163 * * * \\
(-7.70)\end{array}$ & & & & & \\
\hline INDI $_{j}$ & & $\begin{array}{c}0.1371 * * * \\
(41.43)\end{array}$ & & & & \\
\hline $\mathbf{C S R}_{\mathrm{it}} * \mathbf{I N D I}_{\mathrm{j}}$ & & $\begin{array}{c}0.0065 * * * \\
(2.87)\end{array}$ & & & & \\
\hline $\mathrm{MAS}_{\mathrm{j}}$ & & & $\begin{array}{c}-0.0520 * * * \\
(-27.56)\end{array}$ & & & \\
\hline $\mathbf{C S R}_{\mathrm{it}} * \mathbf{M A S} \mathbf{S}_{\mathrm{j}}$ & & & $\begin{array}{c}0.0116 * * * \\
(10.95)\end{array}$ & & & \\
\hline $\mathrm{UAI}_{\mathrm{j}}$ & & & & $\begin{array}{c}-0.1634 * * * \\
(-47.92)\end{array}$ & & \\
\hline $\mathbf{C S R}_{\mathrm{it}} * \mathbf{U A} \mathbf{I}_{\mathrm{j}}$ & & & & $\begin{array}{c}-0.0115 * * * \\
(-7.04)\end{array}$ & & \\
\hline $\mathrm{LT}_{\mathrm{j}}$ & & & & & $\begin{array}{c}-0.1449 * * * \\
(-51.75)\end{array}$ & \\
\hline $\operatorname{CSR}_{\mathrm{it}}{ }^{*} \mathbf{L} \mathbf{T}_{\mathrm{j}}$ & & & & & $\begin{array}{c}-0.0025 \\
(-1.35)\end{array}$ & \\
\hline $\mathrm{INDU}_{\mathrm{i}}$ & & & & & & $\begin{array}{l}0.1142 * * * \\
(30.85)\end{array}$ \\
\hline $\operatorname{CSR}_{\mathrm{it}}{ }^{*} \mathbf{I N D U} \mathbf{j}_{\mathrm{j}}$ & & & & & & $\begin{array}{l}0.0100 * * * \\
(4.49)\end{array}$ \\
\hline SIZE $_{\text {it }}$ & $\begin{array}{c}-0.0865 * * * \\
(-22.13)\end{array}$ & $\begin{array}{c}-0.0598 * * * \\
(-15.17)\end{array}$ & $\begin{array}{c}-0.0864 * * * \\
(-22.04)\end{array}$ & $\begin{array}{c}-0.0810 * * * \\
(-20.97)\end{array}$ & $\begin{array}{c}-0.0474 * * * \\
(-11.93)\end{array}$ & $\begin{array}{c}-0.0712 * * * \\
(-18.16)\end{array}$ \\
\hline $\mathrm{BF}_{\text {it }}$ & $\begin{array}{c}-0.0414 * * * \\
(-15.45)\end{array}$ & $\begin{array}{c}-0.0490 * * * \\
(-18.51)\end{array}$ & $\begin{array}{c}-0.0279 * * * \\
(-10.59)\end{array}$ & $\begin{array}{c}-0.0335 * * * \\
(-12.83)\end{array}$ & $\begin{array}{c}-0.0374 * * * \\
(-14.32)\end{array}$ & $\begin{array}{l}-0.0484 \\
(-18.33)\end{array}$ \\
\hline $\mathrm{ROA}_{\mathrm{it}-1}$ & $\begin{array}{c}-0.0997 * * * \\
(-18.24)\end{array}$ & $\begin{array}{c}-0.0852 * * * \\
(-15.61)\end{array}$ & $\begin{array}{c}-0.1044 * * * \\
(-19.28)\end{array}$ & $\begin{array}{c}-0.0835 * * * \\
(-15.30)\end{array}$ & $\begin{array}{c}-0.0869 * * * \\
(-15.99)\end{array}$ & $\begin{array}{c}-0.0871 * * * \\
(-15.90)\end{array}$ \\
\hline $\mathrm{LEV}_{\text {it }}$ & $\begin{array}{c}-0.0009 \\
(-0.30)\end{array}$ & $\begin{array}{c}-0.0011 \\
(-0.37)\end{array}$ & $\begin{array}{l}-0.0026 \\
(-0.83)\end{array}$ & $\begin{array}{c}0.0004 \\
(0.13)\end{array}$ & $\begin{array}{c}-0.0024 \\
(-0.78)\end{array}$ & $\begin{array}{l}0.0008 \\
(0.26)\end{array}$ \\
\hline $\mathrm{SG}_{\mathrm{it}}$ & $\begin{array}{l}0.0513 \\
(11.90)\end{array}$ & $\begin{array}{c}0.0496 * * * \\
(11.52)\end{array}$ & $\begin{array}{l}0.0523 * * * \\
(12.12)\end{array}$ & $\begin{array}{c}0.0467 * * * \\
(10.83)\end{array}$ & $\begin{array}{c}0.0496 * * * \\
(11.53)\end{array}$ & $\begin{array}{c}0.0491 * * * \\
\quad(11.38)\end{array}$ \\
\hline $\mathrm{RM}_{\mathrm{it}}$ & $\begin{array}{c}0.0870 * * * \\
(27.56)\end{array}$ & $\begin{array}{c}0.0677 * * * \\
(21.13)\end{array}$ & $\begin{array}{l}0.0877 * * * \\
(28.26)\end{array}$ & $\begin{array}{c}0.0767 * * * \\
(24.58)\end{array}$ & $\begin{array}{c}0.0663 * * * \\
(20.89)\end{array}$ & $\begin{array}{l}0.0774 * * * \\
(24.53)\end{array}$ \\
\hline $\mathrm{GDP}_{\mathrm{it}}$ & $\begin{array}{c}0.0375 * * * \\
(10.78)\end{array}$ & $\begin{array}{c}0.0764 * * * \\
(28.23)\end{array}$ & $\begin{array}{c}0.0114 * * * \\
(4.33)\end{array}$ & $\begin{array}{c}-0.0916 * * * \\
(-23.16)\end{array}$ & $\begin{array}{c}0.0391 * * * \\
(15.41)\end{array}$ & $\begin{array}{l}0.0726 \\
(24.36) \\
\end{array}$ \\
\hline Prob > F & $0,0000 * * *$ & $0,0000 * * *$ & $0,0000 * * *$ & $0,0000 * * *$ & $0,0000 * * *$ & $0,0000 * * *$ \\
\hline Squared R & $11.32 \%$ & $12.35 \%$ & $11.49 \%$ & $12.71 \%$ & $12.85 \%$ & $11.97 \%$ \\
\hline Durbin Watson & 1.78 & 1.79 & 1.78 & 1.80 & 1.80 & 1.79 \\
\hline VIF maximum & 4.37 & 4.40 & 4.37 & 4.41 & 4.41 & 4.42 \\
\hline Year fixed effects & Yes & Yes & Yes & Yes & Yes & Yes \\
\hline Industry fixed effects & Yes & Yes & Yes & Yes & Yes & Yes \\
\hline Country fixed effects & No & No & No & No & No & No \\
\hline $\begin{array}{l}\text { Observations } \\
\text { Joint tests F-statistics }\end{array}$ & 157,080 & 157,080 & 157,080 & 157,080 & 157,080 & 157,080 \\
\hline $\mathrm{CSR}_{\mathrm{it}}+\mathrm{CSR}_{\mathrm{it}} * \mathrm{CN}_{\mathrm{j}}=0$ & $0,0000 * * *$ & $0,0000 * * *$ & $0,0000 * * *$ & $0,0000 * * *$ & $0,0000 * * *$ & $0,0000 * * *$ \\
\hline
\end{tabular}


Table 7

Results of influence of national culture on the relationship between CSR and EM

\begin{tabular}{|c|c|c|c|c|c|c|}
\hline & $\begin{array}{c}\mathbf{E M}_{\mathrm{it}} \\
\beta \\
(1) \\
\end{array}$ & $\begin{array}{c}\mathbf{E M}_{\mathrm{it}} \\
\beta \\
(2) \\
\end{array}$ & $\begin{array}{c}\mathbf{E M}_{\mathrm{it}} \\
\beta \\
(3) \\
\end{array}$ & $\begin{array}{c}\mathbf{E M}_{\mathrm{it}} \\
\beta \\
(4) \\
\end{array}$ & $\begin{array}{c}\mathbf{E M}_{\text {it }} \\
\beta \\
(5) \\
\end{array}$ & $\begin{array}{c}\mathbf{E} \mathbf{M}_{\text {it }} \\
\beta \\
(6)\end{array}$ \\
\hline Constant & $\begin{array}{c}- \\
(14.31)\end{array}$ & $(2.35)$ & $\begin{array}{c}- \\
(16.91)\end{array}$ & $\begin{array}{c}- \\
(25.59)\end{array}$ & $\begin{array}{c}- \\
(12.96)\end{array}$ & $(2.39)$ \\
\hline $\mathrm{CSR}_{\mathrm{it}}$ & $\begin{array}{c}-0.0868 * * * \\
(-7.77)\end{array}$ & $\begin{array}{c}-0.0785 * * * \\
(-7.16)\end{array}$ & $\begin{array}{c}-0.0823 * * * \\
(-7.74)\end{array}$ & $\begin{array}{c}-0.0391 * * * \\
(-3.75)\end{array}$ & $\begin{array}{c}-0.0685 * * * \\
(-6.49)\end{array}$ & $\begin{array}{c}-0.0801 * * * \\
(-7.26)\end{array}$ \\
\hline $\mathrm{PD}_{\mathrm{j}}$ & $\begin{array}{c}-0.0723 * * * \\
(-8.67)\end{array}$ & & & & & \\
\hline $\mathrm{CSR}_{\mathrm{it}} * \mathbf{P D}_{\mathrm{j}}$ & $\begin{array}{c}-0.0277 * * * \\
(-4.08)\end{array}$ & & & & & \\
\hline INDI $_{j}$ & & $\begin{array}{c}0.2053 * * * \\
(25.92)\end{array}$ & & & & \\
\hline $\mathbf{C S R}_{\mathrm{it}} * \mathbf{I N D I} \mathrm{j}_{\mathrm{j}}$ & & $\begin{array}{l}0.0150 * * \\
(2.25)\end{array}$ & & & & \\
\hline $\mathrm{MAS}_{\mathrm{j}}$ & & & $\begin{array}{c}-0.1032 * * * \\
(-16.33)\end{array}$ & & & \\
\hline $\mathbf{C S R}_{\mathrm{it}} * \mathbf{M A S} \mathrm{S}_{\mathrm{j}}$ & & & $\begin{array}{c}0.0423 * * * \\
(6.93)\end{array}$ & & & \\
\hline $\mathrm{UAI}_{\mathrm{j}}$ & & & & $\begin{array}{c}-0.2685 * * * \\
(-37.75)\end{array}$ & & \\
\hline $\mathbf{C S R}_{\mathrm{it}} * \mathbf{U A} \mathbf{I}_{\mathrm{j}}$ & & & & $\begin{array}{c}-0.0059 \\
(-1.02)\end{array}$ & & \\
\hline $\mathrm{LT}_{\mathrm{j}}$ & & & & & $\begin{array}{c}-0.2248 * * * \\
(-32.24)\end{array}$ & \\
\hline $\operatorname{CSR}_{\mathrm{it}}{ }^{*} \mathbf{L} \mathbf{T}_{\mathrm{j}}$ & & & & & $\begin{array}{c}-0.0033 \\
(-0.52)\end{array}$ & \\
\hline $\mathrm{INDU}_{\mathrm{i}}$ & & & & & & $\begin{array}{c}0.1631 * * * \\
(20.87)\end{array}$ \\
\hline $\operatorname{CSR}_{\mathrm{it}}{ }^{*} \mathbf{I N D U} \mathrm{U}_{\mathrm{j}}$ & & & & & & $\begin{array}{c}0.0270 * * * \\
(3.99)\end{array}$ \\
\hline SIZE $_{\text {it }}$ & $\begin{array}{c}-0.0260 * * * \\
(-4.39)\end{array}$ & $\begin{array}{c}-0.0129 * * \\
(-2.21)\end{array}$ & $\begin{array}{c}-0.0288 * * * \\
(-4.88)\end{array}$ & $\begin{array}{c}-0.0332 * * * \\
(-5.73)\end{array}$ & $\begin{array}{c}0.0032 \\
(0.55)\end{array}$ & $\begin{array}{c}-0.0103^{*} \\
(-1.75)\end{array}$ \\
\hline $\mathrm{BF}_{\text {it }}$ & $\begin{array}{c}-0.0128 \\
(-2.17)^{* *}\end{array}$ & $\begin{array}{c}-0.0276 * * * \\
(-4.82)\end{array}$ & $\begin{array}{c}0.0135 * * \\
(2.37)\end{array}$ & $\begin{array}{l}-0.0055 \\
(-0.99)\end{array}$ & $\begin{array}{c}-0.0145^{* *} \\
(-2.58)\end{array}$ & $\begin{array}{c}-0.0225 * * * \\
(-3.92)\end{array}$ \\
\hline $\mathrm{ROA}_{\mathrm{it}-1}$ & $\begin{array}{c}0.0010 \\
(0.20)\end{array}$ & $\begin{array}{c}0.0047 \\
(0.91)\end{array}$ & $\begin{array}{c}-0.0026 \\
(-0.51)\end{array}$ & $\begin{array}{c}0.0037 \\
(0.72)\end{array}$ & $\begin{array}{c}-0.0004 \\
(-0.08)\end{array}$ & $\begin{array}{c}0.0018 \\
(0.35)\end{array}$ \\
\hline $\mathrm{LEV}_{\text {it }}$ & $\begin{array}{c}0.0051 \\
(0.98)\end{array}$ & $\begin{array}{c}0.0033 \\
(0.65)\end{array}$ & $\begin{array}{l}9.59 \mathrm{e}-06 \\
(0.00)\end{array}$ & $\begin{array}{c}-0.0020 \\
(-0.39)\end{array}$ & $\begin{array}{c}0.0005 \\
(0.11)\end{array}$ & $\begin{array}{c}0.0046 \\
(0.89)\end{array}$ \\
\hline $\mathrm{SG}_{\text {it }}$ & $\begin{array}{c}0.0754 * * * \\
(14.77)\end{array}$ & $\begin{array}{c}0.0761 * * * \\
(15.06)\end{array}$ & $\begin{array}{c}0.0752 * * * \\
14.73\end{array}$ & $\begin{array}{c}0.0676 * * * \\
(13.51)\end{array}$ & $\begin{array}{c}0.0741 * * * \\
(14.76)\end{array}$ & $\begin{array}{c}0.0746 * * * \\
(14.71)\end{array}$ \\
\hline $\mathrm{RM}_{\mathrm{it}}$ & $\begin{array}{c}0.0639 * * * \\
(12.08)\end{array}$ & $\begin{array}{c}0.0328 * * * \\
(6.17)\end{array}$ & $\begin{array}{l}0.0675 \\
(12.93)\end{array}$ & $\begin{array}{c}0.0412 * * * \\
(7.99)\end{array}$ & $\begin{array}{c}0.0300 * * * \\
(5.73)\end{array}$ & $\begin{array}{c}0.0487 * * * \\
(9.26)\end{array}$ \\
\hline $\mathrm{GDP}_{\mathrm{it}}$ & $\begin{array}{c}0.0548 * * * \\
(7.78) \\
\end{array}$ & $\begin{array}{c}0.1044 * * * \\
(15.72) \\
\end{array}$ & $\begin{array}{c}0.0086 \\
(1.46) \\
\end{array}$ & $\begin{array}{c}-0.1539 * * * \\
(-21.56) \\
\end{array}$ & $\begin{array}{c}0.0521 * * * \\
(8.83) \\
\end{array}$ & $\begin{array}{c}0.0844 * * * \\
(12.88) \\
\end{array}$ \\
\hline $\begin{array}{l}\text { Prob }>\mathrm{F} \\
\text { Adjusted R } \\
\text { Durbin Watson }\end{array}$ & $\begin{array}{c}0.0000 * * * \\
6.50 \%\end{array}$ & $\begin{array}{c}0.0000 * * * \\
8.56 \%\end{array}$ & $\begin{array}{c}0.0000 * * * \\
6.74 \%\end{array}$ & $\begin{array}{c}0.0000 * * * \\
10.52 \%\end{array}$ & $\begin{array}{c}0.0000 * * * \\
9.79 \%\end{array}$ & $\begin{array}{c}0.0000 * * * \\
4.96 \%\end{array}$ \\
\hline VIF maximum & 5.00 & 4.93 & 4.55 & 4.56 & 4.62 & \\
\hline Year fixed effects & Yes & Yes & Yes & Yes & Yes & Yes \\
\hline Industry fixed effects & Yes & Yes & Yes & Yes & Yes & Yes \\
\hline Country fixed effects & No & No & No & No & No & No \\
\hline $\begin{array}{l}\text { Observations } \\
\text { Join-F teste }\end{array}$ & 37,428 & 37,428 & 37,428 & 37,428 & 37,428 & 37,428 \\
\hline $\mathrm{CSR}_{\mathrm{it}}+\mathrm{CSR}_{\mathrm{it}} * \mathrm{CN}_{\mathrm{j}}=0$ & $0,0000 * * *$ & $0,0000 * * *$ & $0,0000 * * *$ & $0,0003 * * *$ & $0,0000 * * *$ & $0,0000 * * *$ \\
\hline
\end{tabular}

